\title{
Uncertainty in pressure difference of empirical geobarometers
}

\author{
Takeshi IKedA ${ }^{*}$, Kazuhiro MiYAZAKI ${ }^{* *}$ and Hirohisa MatsuURA ${ }^{* *}$ \\ *Department of Earth and Planetary Sciences, Kyushu University, 744 Motooka, Fukuoka 819-0395, Japan \\ ${ }^{* *}$ Geological Survey of Japan, AIST, Higashi 1-1-1, central 7, Tsukuba 305-8561, Japan
}

This study evaluates uncertainty in pressure difference of empirical geobarometers derived from thermodynamic properties, which is expressed as:

$$
\sigma_{P_{2}-P_{1}}^{2}=\left(\frac{T_{2}-T_{1}}{\Delta V} \sigma_{\Delta S}\right)^{2}+\left(\frac{P_{2}-P_{1}}{\Delta V} \sigma_{\Delta V}\right)^{2} .
$$

The uncertainty is independent of enthalpy and its uncertainty, and increases mainly with increasing temperature difference. Examination of several empirical geobaromters reveals that the uncertainty in pressure difference is smaller than that in pressure estimation by a factor of at least one third within the temperature range of almost every single metamorphic complex.

Keywords: Geobarometers, Pressure difference, Uncertainty

\section{INTRODUCTION}

Thermobaric structure of a metamorphic complex provides important information on the location and scale of heat source of metamorphism and crustal deformation during exhumation of the complex. Revealing the thermobaric structure has relied mainly upon geothermobarometry. The uncertainty of geobarometers stems from numerous factors such as thermodynamic properties, activity model, analytical errors of mineral chemistry and ambiguity in interpretation of microstructures (e.g., Kohn and Spear, 1991; Spear, 1993). The first factor leads to the magnitude of uncertainty in pressure $\left(\sigma_{P}\right)$ generally comparable to $100 \mathrm{MPa}$ (e.g., Hodges and McKenna, 1987; Kohn and Spear, 1991; Eckert et al. 1991). An error of $100 \mathrm{MPa}$ in estimated pressure corresponds to the ambiguity in crustal depth of about $3.6 \mathrm{~km}$. This feature causes difficulty in deciphering precise thermobaric structures in metamorphic complexes, and thus in employing them as constraints to evaluate the validity of any numerical models of crustal evolution. Especially for low-pressure $(P)$ and high-temperature $(T)$ type met-

doi:10.2465/jmps.170424

T. Ikeda, ikeda@geo.kyushu-u.ac.jp Corresponding author

K. Miyazaki, kazu-miyazaki@aist.go.jp

H. Matsuura, h.matsuura@aist.go.jp amorphic complexes, the pressure estimation with $\sigma_{P}$ of $100 \mathrm{MPa}$ cannot provide more useful information than presence of sillimanite or andalusite at middle-grade.

On the other hand, pressure difference between the distant samples in a single metamorphic complex is also valuable to estimate an apparent pressure gradient. This feature enables to recognize change in crustal thickness during exhumation. Therefore, the evaluation of the magnitude of uncertainty in estimated pressure difference, $\sigma_{P_{2}-P_{1}}$, is also important. It is pointed out that the pressure difference between samples obtained by a single geobarometer involves much smaller uncertainty than the pressure estimation because the uncertainties derived from thermodynamic properties are cancelled out (Kohn and Spear, 1991; Spear, 1993). Ikeda et al. (2017) evaluate $\sigma_{P_{2}-P_{1}}$ of two geobarometers of Hoisch (1990) as 10 $\mathrm{MPa}$, much smaller than $\sigma_{P}$ for samples with temperature difference of $210{ }^{\circ} \mathrm{C}$, whereby they enable to detect crustal thinning during retrograde stage of the metamorphism. However, it is still not shown in the general form how precise the pressure difference is determined.

This study presents the general expression that describes $\sigma_{P_{2}-P_{1}}$, and examines the magnitude of $\sigma_{P_{2}-P_{1}}$ of several empirical geobarometers. 


\section{ESTIMATION OF PRESSURE DIFFERENCE}

The geobarometry employs fluid-independent reactions that describe stoichiometric relation among phase components expressed as:

$$
0=\sum_{i} v_{i} \Phi_{i}
$$

where $\Phi_{i}$ and $v_{i}$ represent molar chemical formula of phase component $i$ and its stoichiometric coefficient, respectively. The equilibrium condition may be described as a function of $P, T$, and equilibrium constant $(K)$ in the form:

$$
0=\Delta H-T \Delta S+P \Delta V+R T \ln K
$$

where $R$ represents gas constant. Changes of enthalpy, entropy and volume of reaction 1 , referred to as $\Delta H, \Delta S$, and $\Delta V$, respectively, are usually treated as constant at pressures for crustal depth. Rewriting Eq. 2 shows:

$$
P=-\frac{\Delta H}{\Delta V}+\frac{\Delta S-R \ln K}{\Delta V} T
$$

This equation represents a line denoted as isopleth for a value of $K$ in $P-T$ space. The reactions with large $\Delta V$, corresponding mostly to net-transfer reactions, are used as geobarometer while exchange reactions with small $\Delta V$ are used as geothermometer.

Consider two samples of which temperature is known as $T_{1}$ and $T_{2}$, and their equilibrium constant of the reaction used as geobarometer is $K_{1}$ and $K_{2}$. Subtraction of Eq. 3 for each sample yields the following equation that describes pressure difference between the samples, $P_{2}-P_{1}$ (Ikeda, 2004):

$$
P_{2}-P_{1}=\frac{\Delta S}{\Delta V}\left(T_{2}-T_{1}\right)-\frac{R T_{2} \ln K_{2}-R T_{1} \ln K_{1}}{\Delta V}
$$

It is emphasized that the pressure difference can be described without information of $\Delta H$.

\section{UNCERTAINTY OF PRESSURE AND PRESSURE DIFFERENCE}

For the construction of conventional geobarometer, three constants in Eq. 3, $\Delta H, \Delta S$, and $\Delta V$, are determined by compiling the thermodynamic properties of minerals or by experiments for the end-member reaction shown as Eq. 1 , in which $K$ is unity. The choice of activity model is independent of this procedure, suggesting that $\sigma_{P}$ of the conventional geobarometer stems not only from the thermodynamic properties but also from the activity models and equilibrium constant.

In contrast, empirical geobarometer employs the reactions which contain plural phase components for a single mineral. For instance, the reaction almandine +2 grossular + muscovite $=3$ anorthite + annite contains two components for garnet. It is unable to experimentally determine the $P-T$ position of the end-member reactions directly because a solid solution mineral cannot have pure composition for more than one phase component simultaneously. In the above example, pure almandine never coexists with pure grossular. Alternatively, the thermodynamic properties in Eq. 3 are determined by setting activity models beforehand. A set of chemical composition of the coexisting minerals, of which equilibrium $P-T$ condition is determined experimentally or by conventional geothermobarometry, provides an equilibrium constant $K$ according to the adopted activity models. Substituting these values $(P, T$, and $K)$ into Eq. 3 yields an equation that contains three variables $\Delta H / \Delta V, \Delta S / \Delta V$, and $1 / \Delta V$. Multiple regression of plural samples gives a reliable solution as the averages with their standard deviations that are mutually correlated. The uncertainties in pressure and pressure difference of the empirical geobarometers may be, therefore, evaluated based on the assumption that the activity model of minerals is well-established for the relevant geobarometer.

The magnitude of uncertainty in $\Delta V$, i.e., $\sigma_{\Delta V}$ is directly obtained from the standard deviation of $1 / \Delta V$. Those in $\Delta H$ and $\Delta S$, denoted as $\sigma_{\Delta H}$ and $\sigma_{\Delta S}$, respectively, are obtained by the general expression of error propagation (cf. Spear, 1993):

$$
\sigma_{Z}^{2}=\sum_{i} \sum_{j}\left(\frac{\partial Z}{\partial x_{i}}\right)\left(\frac{\partial Z}{\partial x_{j}}\right) \sigma_{i} \sigma_{j} r_{i j}
$$

where $Z$ is a parameter as a function of variables $x_{i}$ and $x_{j}$. This corresponds to $\Delta H$ and $\Delta S$ in this stydy. The variables $x_{i}$ and $x_{j}$ show two of three $\Delta H / \Delta V, \Delta S / \Delta V$, and $1 / \Delta V$, and $r_{i j}$ refers to the correlation coefficient between the two variables. The obtained $\sigma_{\Delta H}, \sigma_{\Delta S}$, and $\sigma_{\Delta V}$ are mutually independent, and are responsible for the uncertainties in pressure and pressure difference. Applying the general expression that represents propagation of uncertainties derived from independent variables (cf. Taylor, 1997) to Eq. 3 yields $\sigma_{P}$ as a function of $\sigma_{\Delta H}, \sigma_{\Delta S}$, and $\sigma_{\Delta V}$ expressed as:

$$
\sigma_{P}^{2}=\left(\frac{1}{\Delta V} \sigma_{\Delta H}\right)^{2}+\left(\frac{T}{\Delta V} \sigma_{\Delta S}\right)^{2}+\left(\frac{P}{\Delta V} \sigma_{\Delta V}\right)^{2}
$$


Table 1. List of empirical geobarometers investigated in this study

\begin{tabular}{|c|c|c|c|}
\hline Geobarometer & Assemblage & Reaction & Reference \\
\hline H90R1 & Grt-Bt-Pl-Qtz & $\begin{array}{l}1 / 3 \text { pyrope }+2 / 3 \text { grossular }+ \text { eastonite }+2 \text { quartz } \\
\quad=2 \text { anorthite }+ \text { phlogopite }\end{array}$ & 1 \\
\hline H90R2 & Grt-Bt-Pl-Qtz & $\begin{array}{l}1 / 3 \text { almanidine }+2 / 3 \text { grossular }+ \text { siderophyllite }+2 \text { quartz } \\
=2 \text { anorthite }+ \text { phlogopite }\end{array}$ & 1 \\
\hline H90R3 & Grt-Ms-Pl-Qtz & $\begin{array}{l}1 / 3 \text { pyrope }+2 / 3 \text { grossular }+ \text { muscovite }+2 \text { quartz } \\
=2 \text { anorthite }+\mathrm{MgAl} \text { celadonite }\end{array}$ & 1 \\
\hline H90R4 & Grt-Bt-Ms-Pl-Qtz & $\begin{array}{l}1 / 3 \text { grossular }+1 / 3 \text { phlogopite }+2 / 3 \text { muscovite }+2 \text { quartz } \\
=\text { anorthite }+\mathrm{MgAl} \text { celadonite }\end{array}$ & 1 \\
\hline H90R5 & Grt-Bt-Ms-Pl & pyrope + grossular + muscovite $=3$ anorthite + phlogopite & 1 \\
\hline H90R6 & Grt-Bt-Ms-Pl & almandine + grossular + muscovite $=3$ anorthite + annite & 1 \\
\hline GS81R1 & Grt-Bt-Ms-Pl & pyrope + grossular + muscovite $=3$ anorthite + phlogopite & 2 \\
\hline $\mathrm{HC} 85 \mathrm{R} 3$ & Grt-Bt-Ms-Pl & almandine + grossular + muscovite $=3$ anorthite + annite & 3 \\
\hline $\mathrm{HC} 85 \mathrm{R} 4$ & Grt-Bt-Ms-Pl-Qtz & $\begin{array}{l}\text { almandine }+2 \text { grossular }+3 \text { muscovite }+6 \text { quartz } \\
\quad=6 \text { anorthite }+3 \mathrm{FeAl} \text { celadonite }\end{array}$ & 3 \\
\hline HC85R5 & Grt-Bt-Ms-Pl-Qtz & grossular + annite +2 muscovite +6 quartz $=3$ anorthite $+3 \mathrm{FeAl}$ celadonite & 3 \\
\hline HC85R11S & Sil-Grt-Bt-Ms-Pl & $\begin{array}{l}\text { annite }+2 \text { muscovite }+15 \text { anorthite } \\
\quad=5 \text { grossular }+3 \mathrm{FeAl} \text { celadonite }+12 \text { sillimanite }\end{array}$ & 3 \\
\hline HC85R11K & Ky-Grt-Bt-Ms-Pl & $\begin{array}{l}\text { annite }+2 \text { muscovite }+15 \text { anorthite } \\
\quad=5 \text { grossular }+3 \mathrm{FeAl} \text { celadonite }+12 \text { kyanite }\end{array}$ & 3 \\
\hline KS90a & Grt-Hbl-Pl-Qtz & 6 anorthite +3 tremolite $=2$ grossular + pyrope +3 tschermakite +6 quartz & 4 \\
\hline KS90b & Grt-Hbl-Pl-Qtz & $\begin{array}{l}6 \text { anorthite }+3 \mathrm{Fe} \text {-actinolite } \\
\quad=2 \text { grossular }+ \text { almandine }+3 \text { Fe-tschermakite }+6 \text { quartz }\end{array}$ & 4 \\
\hline GAPES & Grt-Opx-Pl-Qtz & anorthite + enstatite $=2 / 3$ pyrope $+1 / 3$ grossular + quartz & 5 \\
\hline GADS & Grt-Cpx-Pl-Qtz & anorthite + diopside $=1 / 3$ pyrope $+2 / 3$ grossular + quartz & 5 \\
\hline
\end{tabular}

Abbreviations: Bt, biotite; Grt, garnet; Hbl, hornblende; Ky, kyanite; Ms, muscovite; Pl, plagioclase; Qtz, quartz; Sil, sillimanite. 1, Hoisch (1990); 2, Ghent and Stout (1981); 3. Hodges and Crowley (1985); 4. Kohn and Spear (1990); 5, Newton and Perkins (1982), Eckert et al. (1991).

In contrast, the pressure difference is obtained without information of $\Delta H$ (Eq. 4), as described before. Therefore the pressure difference involves $\Delta S$ and $\Delta V$ as the source of uncertainty. Applying again the general expression of error propagation of independent $\sigma_{\Delta S}$ and $\sigma_{\Delta V}$ provides the uncertainty of pressure difference as:

$$
\sigma_{P_{2}-P_{1}}^{2}=\left(\frac{T_{2}-T_{1}}{\Delta V} \sigma_{\Delta S}\right)^{2}+\left(\frac{P_{2}-P_{1}}{\Delta V} \sigma_{\Delta V}\right)^{2}
$$

Equation 7 represents a general expression that evaluates $\sigma_{P_{2}-P_{1}}$ derived from the uncertainties of thermodynamic properties of the reaction. Comparison of Eq. 7 with Eq. 6 emphasizes that not only the term $\sigma_{\Delta H}$ disappears but also the terms $\sigma_{\Delta S}$ and $\sigma_{\Delta V}$ are multiplied by temperatureand pressure-differences, respectively, that are much smaller than absolute temperature and pressure. This suggests that $\sigma_{P_{2}-P_{1}}$ is significantly smaller than $\sigma_{P}$.

Use of different geobarometers with similar $\sigma_{P}$ pro- vides the magnitude of $\sigma_{P_{2}-P_{1}}$ larger than $\sigma_{P}$ by a factor of about $\sqrt{2}$. In contrast, the difference in pressure using the same geobarometer is expressed as Eq. 4. Evaluating $\sigma_{P_{2}-P_{1}}$ directly from Eq. 4 leads to the present conclusion. Kohn and Spear (1991) indicate that the uncertainties of thermodynamic properties cancel out in estimating pressure difference based on the same geobarometer. This assertion is appropriate only when temperatures of two samples are identical with assuming $\sigma_{\Delta V}=0$.

\section{EXAMINATION OF EMPIRICAL GEOBAROMETERS}

We estimate $\sigma_{P}$ and $\sigma_{P_{2}-P_{1}}$ derived from $\sigma_{\Delta H}, \sigma_{\Delta S}$, and $\sigma_{\Delta V}$ for the empirical geobarometers listed in Table 1. For this evaluation, we need information of $\sigma_{\Delta H}, \sigma_{\Delta S}$, and $\sigma_{\Delta V}$, or alternatively $\sigma_{\Delta H / \Delta V}, \sigma_{\Delta S / \Delta V}$, and $\sigma_{1 / \Delta V}$ together with the set of $r_{i j}$ that appears in Eq. (5). Kohn and Spear (1990) show the latter infromation, and the values of $\sigma_{\Delta H}$ and $\sigma_{\Delta S}$ are 
Table 2. Thermodynamic properties with their uncertainties and uncertainties in pressure and pressure difference

\begin{tabular}{|c|c|c|c|c|c|c|c|c|c|c|}
\hline \multirow[b]{2}{*}{ Geobarometer } & \multirow{2}{*}{$\begin{array}{r}\Delta H \\
(\mathrm{~J})\end{array}$} & \multirow{2}{*}{$\begin{array}{r}\sigma_{\Delta H} \\
(\mathrm{~J})\end{array}$} & \multirow{2}{*}{$\begin{array}{c}\Delta S \\
(\mathrm{~J} / \mathrm{K})\end{array}$} & \multirow{2}{*}{$\begin{array}{l}\sigma_{\Delta S} \\
(\mathrm{~J} / \mathrm{K})\end{array}$} & \multirow{2}{*}{$\begin{array}{c}\Delta V\left(10^{5}\right) \\
(\mathrm{J} / \mathrm{Pa})\end{array}$} & \multirow{2}{*}{$\begin{array}{c}\sigma_{\Delta V}\left(10^{5}\right) \\
(\mathrm{J} / \mathrm{Pa})\end{array}$} & \multirow{2}{*}{$\begin{array}{l}\sigma_{P}{ }^{*} \\
(\mathrm{MPa}) \Delta T\left({ }^{\circ} \mathrm{C}\right)\end{array}$} & \multicolumn{3}{|c|}{$\sigma_{P_{2}}-\sigma_{P_{1}}^{* *}(\mathrm{MPa})$} \\
\hline & & & & & & & & 0 & 200 & 400 \\
\hline H90R 1 & 31830.6 & 1284.4 & 79.0281 & 1.6027 & 3.81446 & 0.05481 & 55 & 3 & 9 & 17 \\
\hline H90R2 & 46707.2 & 1419.2 & 85.5824 & 1.5880 & 3.89856 & 0.005227 & 55 & 0 & 8 & 16 \\
\hline H90R3 & 20681.4 & 2796.1 & 69.8341 & 4.2334 & 4.17399 & 0.14807 & 123 & 7 & 22 & 41 \\
\hline H90R4 & 21664.0 & 2027.1 & 33.7500 & 3.0804 & 2.19415 & 0.10862 & 171 & 10 & 30 & 57 \\
\hline H90R5 & 3546.01 & 4100.13 & 121.347 & 5.182 & 6.37161 & 0.21862 & 106 & 7 & 18 & 33 \\
\hline H90R6 & 55530.4 & 4094.7 & 140.635 & 5.803 & 6.59940 & 0.21807 & 109 & 7 & 19 & 36 \\
\hline GS81R1 & -37188.4 & 2093.0 & 69.802 & 4.186 & 7.27527 & 0 & 64 & 0 & 12 & 23 \\
\hline HC85R3 & 69965 & 12372 & 162.992 & 14.527 & 7.5400 & 0 & 253 & 0 & 39 & 77 \\
\hline HC85R4 & 189029 & 31096 & 352.644 & 35.719 & 15.6432 & 0 & 303 & 0 & 46 & 91 \\
\hline $\mathrm{HC} 85 \mathrm{R} 5$ & 127813 & 21401 & 199.535 & 24.656 & 8.1032 & 0 & 403 & 0 & 61 & 122 \\
\hline HC85R11S & -124432 & 38966 & -579.128 & 43.886 & -24.6460 & 0 & 238 & 0 & 36 & 71 \\
\hline HC85R11K & -214708 & 39047 & -736.280 & 44.446 & -31.6180 & 0 & 187 & 0 & 28 & 56 \\
\hline KS90a & 79507 & 12936 & -29.14 & 15.704 & -10.9880 & 0.65198 & 189 & 12 & 31 & 58 \\
\hline KS90b & 35327 & 15663 & -56.09 & 17.781 & -11.9060 & 0.79382 & 203 & 13 & 33 & 61 \\
\hline GAPES & 8230 & 2520 & -31.048 & 2.679 & -2.373 & 0 & 155 & 0 & 23 & 45 \\
\hline GADS & 6020 & 3470 & -39.738 & 2.679 & -2.312 & 0 & 190 & 0 & 23 & 46 \\
\hline
\end{tabular}

${ }^{*}$ Calculated based on Eq. 6 at nominal $P, T$ of $600 \mathrm{MPa}$ and $727^{\circ} \mathrm{C}$.

** Calculated based on Eq. 7 at nominal pressure difference of $200 \mathrm{MPa}$.

obtained by Eq. 5. Ghent and Stout (1981), Hodges and Crowley (1985), and Eckert et al. (1991) assume $\sigma_{\Delta V}=0$. Hodges and Crowley (1985) examine ten fluid-independent net-transfer reactions and conclude that four of them are useful as geobarometers, which are examined in this study. The regression done by Hoisch (1990) also includes the Margules parameters of activity. They are not taken into account in this study, which provides minimum estimate of the uncertainty.

The obtained $\Delta H, \Delta S$, and $\Delta V$ with their uncertainties are summarized in Table 2. The geobarometers H90R5 and GS81R1 employ the same reaction, as is the case of H90R6 and HC85R3. These two pairs show different thermodynamic properties (Table 2), which is ascribed to the choice of different activity models. The pressure difference is not sensitive to the choice of activity model (cf. Ikeda, 2004). However, use of inadequate activity model may cause large uncertainties in thermodynamic properties. Table 2 also shows $\sigma_{P}$ based on Eq. 6 at a nominal $P-T$ of $727^{\circ} \mathrm{C}(1000 \mathrm{~K})$ and $600 \mathrm{MPa}$, and $\sigma_{P_{2}-P_{1}}$ based on Eq. 7 at nominal temperature differences of 0,200 , and $400{ }^{\circ} \mathrm{C}$ assuming the same pressure difference of $200 \mathrm{MPa}$.

\section{DISCUSSION AND CONCLUSIONS}

The relative uncertainty in $\Delta V$ for most geobarometers is as small as less than 5\%, except for KS90a and KS90b that possess $6-7 \%$. The pressure difference has the same relative uncertainty if temperature is the same, as is clear in Eq. 7. This uncertainty is negligibly small less than 13 $\mathrm{MPa}$ at pressure difference of $200 \mathrm{MPa}$ (Table 2), and does not exceed $20 \mathrm{MPa}$ at pressure difference of $400 \mathrm{MPa}$. Thus the main source in $\sigma_{P_{2}-P_{1}}$ originates from $\Delta S$. The magnitude of $\sigma_{P_{2}-P_{1}}$ increases with increasing temperature difference. For temperature difference of $400{ }^{\circ} \mathrm{C}$, the magnitude of $\sigma_{P_{2}-P_{1}}$ does not still exceed $60 \mathrm{MPa}$ that is approximately one third of $\sigma_{P}$ for most geobarometers. The uncertainties of $60 \mathrm{MPa}$ correspond to the ambiguity in crustal thickness of about $2 \mathrm{~km}$. When we choose a reference condition at middle-grade of a metamorphic complex as $P_{1}-T_{1}$, the metamorphic temperatures at any grade of the complex may not exceed $\pm 400{ }^{\circ} \mathrm{C}$ from $T_{1}$. This indicates that we enable to recognize the relative depth of metamorphic rocks with precision of about $2 \mathrm{~km}$.

Low $-P$ and high- $T$ metamorphic complexes show the field $P-T$ curves that intersect the univariant curve of andalusite $=$ sillimanite. This reaction is located between $530{ }^{\circ} \mathrm{C}, 420 \mathrm{MPa}$ of triple point (Bohlen et al. 1991 ) and about $850^{\circ} \mathrm{C}$ at atmospheric pressure. Supposing we examine the pressure difference along the sillimanite isograd of a metamorphic complex, the maximum temperature difference of $320{ }^{\circ} \mathrm{C}$ brings the maximum $\sigma_{P_{2}-P_{1}}$ of $50 \mathrm{MPa}$. This implies that it may be possible to recognize pressure difference along the isograd. 
The present evaluation may be applicable to the conventional geobarometers to examine $\sigma_{P}$ and $\sigma_{P_{2}-P_{1}}$ derived only from $\Delta H, \Delta S$, and $\Delta V$ of the end-member reactions. The assemblage garnet, plagioclase, kyanite, and quartz (GASP) is extensively used for geobarometry. Newton and Haselton (1981) report $\sigma_{\Delta H}$ and $\sigma_{\Delta S}$ of $1256 \mathrm{~J}$ and $4.186 \mathrm{~J} / \mathrm{K}$, respectively, for the reaction 3 anorthite $=$ grossular +2 kyanite + quartz. This provides $\sigma_{P}$ of $66 \mathrm{MPa}$ at $727^{\circ} \mathrm{C}, 600 \mathrm{MPa}$, while $\sigma_{P_{2}-P_{1}}$ of $25 \mathrm{MPa}$ at temperature differences of $400{ }^{\circ} \mathrm{C}$. This uncertainty is smaller than or comparable to the empirical geobarometers.

The arguments lead to the following conclusions. We present Eq. 7 that evaluates the uncertainty in pressure difference of geobarometers derived from thermodynamic properties. The magnitude of $\sigma_{P_{2}-P_{1}}$ is less than 60 $\mathrm{MPa}$ for most geobarometers examined in this study when temperature difference is less than $400{ }^{\circ} \mathrm{C}$. This suggests that we are able to recognize $2 \mathrm{~km}$ difference in crustal thickness of a metamorphic complex.

\section{ACKNOWLEDGMENTS}

We are grateful to T. Kawakami, I. Ashchepkov, and C-M $\mathrm{Wu}$ for review and $\mathrm{T}$. Tsunogae for editorial handling. This work was financially supported in part by the Japan Society for the Promotion of Science KAKENHI Grant Number JP C25400518.

\section{REFERENCES}

Bohlen, S.R., Montana, A. and Kerrick, D.M. (1991) Precise determination of the equilibria kyanite $\Leftrightarrow$ sillimanite and kyanite $\Leftrightarrow$ andalusite and a revised triple point for $\mathrm{Al}_{2} \mathrm{SiO}_{5}$ polymorphs. American Mineralogist, 76, 677-680.

Eckert, J.O. Jr, Newton, R.C. and Kleppa, O.J. (1991) The $\Delta H$ of reaction and recalibration of garnet-pyroxene-plagioclasequartz geobarometers in the CMAS system by solution calorimetry. American Mineralogist, 76, 148-160.

Ghent, E.D. and Stout, M.Z. (1981) Geobarometry and geother- mometry of plagioclase-biotite-garnet-muscovite assemblages. Contributions to Mineralogy and Petrology, 76, 92-97.

Hodges, K.V. and Crowley, P.D. (1985) Error estimation and empirical geothermobarometry for pelitic systems. American Mineralogist, 70, 702-709.

Hodges, K.V. and McKenna, L.W. (1987) Realistic propagation of uncertainties in geologic thermobarometry. American Mineralogist, 72, 671-680.

Hoisch, T.D. (1990) Empirical calibration of six geobarometers for the mineral assemblage quartz + muscovite + biotite + plagioclase + garnet. Contributions to Mineralogy and Petrology, 104, 225-234.

Ikeda, T. (2004) Pressure-temperature conditions of the Ryoke metamorphic rocks in Yanai district, SW Japan. Contributions to Mineralogy and Petrology, 146, 577-589.

Ikeda, T., Miyazaki, K. and Matsuura, H. (2017) Metamorphic condition of a regional metamorphic complex in the Omuta district in northern Kyushu, southwest Japan. Island Arc. doi: 10.1111/iar.12204.

Kohn, M.J. and Spear, F.S. (1990) Two new geobarometers for garnet amphibolites, with applications to southeastern Vermont. American Mineralogist, 75, 89-96.

Kohn, M.J. and Spear, F.S. (1991) Error propagation for barometers: 2. Application to rocks. American Mineralogist, 76, 138147.

Newton, R.C. and Haselton, H.T. (1981) Thermodynamics of the garnet-plagioclase- $\mathrm{Al}_{2} \mathrm{SiO}_{5}$-quartz geobarometer. In Thermodynamics of Minerals and Melts (Newton, R.C. Ed.). pp. 320, Springer Verlag, New York, 131-147.

Newton, R.C. and Perkins, D. III (1982) Thermodynamic calibration of geobarometers based on the assemblages garnetplagioclase-orthopyroxene (clinopyroxene)-quartz. American Mineralogist, 67, 203-222.

Spear, F.S. (1993) Metamorphic Phase Equilibria and PressureTemperatureTtime Path. Mineralogical Society of America Monograph. Mineralogical Society of America, pp. 799, Washington, DC.

Taylor, J.R. (1997) An introduction to error analysis: the study of uncertainties in physical measurements. 2nd Edition. pp. 327, University Science Books.

Manuscript received April 24, 2017

Manuscript accepted August 2, 2017

Manuscript handled by Toshiaki Tsunogae 